\title{
The evolution of generalised and acute job tenure insecurity
}

\begin{abstract}
An earlier article by Gallie, Felstead, Green and Inanc demonstrates that employee insecurity can be divided into job tenure insecurity (anxieties about the continuity of employment) and job status insecurity (anxieties about the loss of valued features of the job). Here it is argued that job tenure insecurity can be further divided into acute and generalised variants. The former tracks the level of involuntary redundancies in the UK data and is grounded in a realistic assessment of the likelihood of involuntary job loss. The latter is driven by a range of factors, including the economic cycle and the intensification of work that is also associated with rising job status insecurity, and the permeation of insecurity through new sections of the workforce. Its greatest extent was in the mid-1990s and it rose again in the years following the 2008-9 recession.
\end{abstract}

\section{Keywords}

contingent work, human resource management, job insecurity, precarity

\author{
Author \\ Joseph Choonara, University of Leicester School of Business
}

\section{Correspondence}

Joseph Choonara, University of Leicester School of Business, University Road, Leicester LE1 7RH, UK. jc770@le.ac.uk

\section{Introduction: identifying and measuring insecurity}

An earlier article in this journal, 'The hidden face of job insecurity' by Duncan Gallie, Alan Felstead, Francis Green and Hande Inanc (2017, henceforth GFGI) has significantly advanced our understanding of job insecurity. GFGI usefully set out the distinction between what they call 'job tenure insecurity', the anxiety of employees that they may lose their current job, and 'job status insecurity', the fear of the loss of valued features of the job. GFGI also summarize the research on valued features of jobs pertinent to exploring job status insecurity. Furthermore, they produce evidence for a rise in both forms of insecurity between 2000 and 2012 in the UK, and evidence that job status insecurity may be more prevalent than job tenure insecurity. 
This article further contributes to the literature on insecurity in four ways. First, it argues for a refinement of the GFGI approach, distinguishing between two types of job tenure insecurity: 'generalised job tenure insecurity' and 'acute job tenure insecurity'. The latter implies a high level of fear of imminent job loss, the former a more general and muted anxiety. These types of job tenure insecurity evolve in different ways. Second, it proposes that acute job tenure insecurity is rooted in a realistic appraisal by employees of the likelihood of imminent job loss. Third, it presents, in graphical form, a picture of generalised job tenure insecurity, drawing on a larger range of surveys than GFGI and showing the rise in this phenomenon in the UK in the mid-1990s and in the wake of the 2008-9 recession. It is argued that this generalised job tenure insecurity bears less relationship to the real risk of job loss and is instead driven by wider factors, including those linked to the intensification of work and declining job status security. Fourth, it shows that generalised job tenure insecurity has spread through professional groups and, in some periods, also extends to managers. This approach, and in particular the distinction between acute and generalised job tenure insecurity, may open up avenues for future research.

There are several distinct approaches to identifying, conceptualising and measuring insecurity. There is a substantial body of writing stemming from an organisational psychology approach (Cheng and Chan, 2008; Keim et al, 2014). This includes the work of Greenhalgh and Rosenblatt (1984), treated as 'seminal' by GFGI for its distinction between different forms of insecurity. Subsequent literature has also examined the consequences of job insecurity as a source of stress, impaired job performance and satisfaction, psychological distress and reduced perceived well-being (Burchell, 1994; De Witte, 1999; Sverke and Hellgren, 2002; Carr and Chung 2014; Burgard and Steelye, 2016). Indeed subjective insecurity may be more important than objective insecurity in exploring outcomes such as workers sacrificing consumption or postponing marriage, having children or buying a house (Lozza et al, 2012).

While much of this literature has developed complex models of the drivers of insecurity within the workplace, in measuring the prevalence of insecurity the sociology of work literature has tended to follow a more pragmatic approach. This typically involves analysing survey data in which workers are simply asked if they think it is likely that they will lose their job, what they think the likelihood of job loss is or whether they feel secure in their employment. That is certainly the case with the GFGI article; so too with a number of earlier works. For instance, Brendan Burchell (2002) draws on the 1986 Social Change and Economic Life Initiative and the 1997 Skills Survey to examine changes in subjective insecurity in the UK. Burchell (2002:63) justifies a focus on self-reporting by employees by noting that 'it is...perception of the risks associated with their job...which may stress employees and change their motivation and morale'. Comparing the data from two surveys, he finds relatively little change in insecurity, noting with some surprise that 'we became increasingly convinced that the UK in the 1980s and 1990s had indeed witnessed little overall change in job security' (Burchell, 2002:64). Regarding the earlier period, Burchell (2002: 66-68) traces the evolution of insecurity prior to the 1980s using retrospective data. While such data is subject to recall bias, and so needs to be treated cautiously, the analysis suggests relatively stable levels of insecurity from 1967 until approximately 1977. This was followed by a period from 1977 to 1981 in which there was a 'considerable increase in insecurity for all groups, but especially blue-collar workers' (Burchell, 2002:68). 
A comparative study by Francis Green (2009), looking at 31 countries based on data from 1989, 1997 and 2005 , similarly finds 'no grounds for accepting that, at least over this relatively short period, workplaces are going through a sea change in the security of employment'. Green also notes a loose correlation between job insecurity and unemployment. Lowe (2018) uses General Social Survey data from the US, covering 2002, 2006, 2010 and 2014, to examine the evolution of perceived job insecurity, contrasting this with labour market insecurity, seen as the worker's assessment of their capacity to find a new job. Here the data show a modest but not significant decline in job security, especially from 2006 to 2010, with some recovery up to 2014. By contrast, the impact of the most recent recession is deemed significant on labour market insecurity (Lowe, 2018:15, 23). McGann et al (2016: 769) also argue that recent downturns and their associated labour market tightening might transform how workers experience insecurity.

Alongside these approaches to insecurity, there is a body of literature that focuses on the relationship between job insecurity and broad socio-economic changes and, in many cases, questions whether rises in subjective insecurity do indeed reflect a growing precariousness of employment. A range of potential drivers of insecurity have been identified both within and outside the workplace. For instance, Auer and Cazes (2000) argue that the media often 'construct generalised "facts" from scarce evidence of a few micro-level cases', adding that this impression is reinforced by research on non-standard work, in which inferences are made about the overall labour market from a few areas. Fevre (2007) similarly notes an astonishing increase in stories about insecurity in the British media between 1986 and 1996, despite the fact that unemployment was far higher in the former year.

Auer and Cazes (2000) add that fear of job loss has tended to spread in recent years to skilled, whitecollar workers, 'those with a voice'. Indeed, GFGI show that from the 1990s, in contrast with the mid-1980s, job tenure insecurity was experienced by all occupational groupings, including those in managerial and professional roles. A more recent article, Hassard and Morris (2018), offers a qualitative study of managerial insecurity in the US, UK and Japan, focusing on managers in large corporations, affirming that insecurity has permeated more thoroughly into this section of the workforce.

Hassard and Morris draw on a more general argument by Kevin Doogan (2009) regarding the development of 'contrived competition' in the neoliberal period, which Doogan identifies with efforts to reorient government policy to increase the exposure of the economy to market forces. Doogan argues that by the 1990s, as a result of a turn to neoliberal policies, a managerial language had come to predominate, stressing the extent to which internal flexibility and adaptability were the prerequisites for profitability and success in the market (Doogan, 2009: 32).

Doogan's account goes further than many in suggesting a 'manufactured uncertainty' (Doogan 2009: 202) characteristic of the neoliberal period. This draws on earlier discussions of 'précarité' encountered in the writing of French sociologists from the 1970s, following the earlier use of the term by Pierre Bourdieu (1963). Although the term would come to convey a broad range of meanings (Barbier, 2002), for Bourdieu (1998: 82-85) it increasingly denoted a form of domination characterised by engendered insecurity.

The greater penetration of market forces can also increase the consequences of job loss, as traditional forms of welfare are undermined in favour of a workfare approach (Deeming, 2015). This 
can further increase perceptions of insecurity regardless of the actual probability of job loss. Both consequences of job loss and the pressures of increased performance demands by employers feature in the comparative study of insecurity in former East and West German regions by Bernhardt and Krause (2014). For workers in standard employment relations, they find that in the West demands for greater performance were perceived as threatening security, whereas in the East these measures are accepted largely due to the higher risks of unemployment; in the latter case higher performance and flexibility are seen as part of an implicit contract in return for greater security.

These types of account permit subjective insecurity to be detached from the objective insecurity or precarity of employment, as measured by the prevalence of temporary contracts or the actual tenure of employment, both of which have proved relatively stable in the UK since the 1980s (Fevre, 2007; Gregg et al, 2011; Choonara, 2019). Indeed, recent discussions of precarity in this journal have emphasised the need to explore both subjective and objective aspects (see, for instance, Alberti et al, 2018).

\section{Acute and generalised job tenure insecurity}

The hypothesis here, which, as with the GFGI article, is tested using UK data, is that aggregate measures of subjective job tenure insecurity in surveys of employees in practice contain two different elements. On the one hand, there are well-grounded fears of job loss generated by developments within workplaces. Here this will be termed acute job tenure insecurity. On the other hand, a more general uncertainty and unease about the continuity of employment will be termed generalised job tenure insecurity, and it is hypothesised that this is driven the broader ideological climate, including factors operating outside of workplaces.

One factor that could be expected to heighten generalised job tenure insecurity is the impact of economic recessions and their aftermath. There are several transmission channels for this. Following the early 1980s recession, whose impact was focused largely on manufacturing with substantial job losses and plant closures, subsequent recessions in the early 1990s and in 2008-9 impacted in a more generalised way across the labour force, for instance through the prolonged period of austerity and wage suppression following the 2008-9 recession (Doogan, 2011). The result might well be to increase generalised job tenure insecurity even among those workers whose jobs are not in any imminent danger of losing their jobs.

Furthermore, changes in the nature of work, which tend to increase job status insecurity, can raise job tenure insecurity. It is well known that job tenure insecurity increases where changes such as increasing workload, wage freezes or restrictions on overtime take place (Wanrooy et al, 2013: 8-9). Similarly, Burchell (2002: 70) reports that in a survey in the late 1990s about 40 percent of those who thought it was unlikely that they would lose their job still said their job was 'very insecure', 'insecure' or 'neither secure nor insecure'. GFGI show an increase in job status insecurity in the period following 2008-9. There is also substantial evidence of such a deterioration in workplace conditions following the 1991-2 recession (Burchell, 2002: 73-74; Overell et al, 2010: 68; Green, 2007; Green, 2011). According to Green (2007: 64) work intensification continued until 1997 before levelling out. 
There also tend to be increases in temporary employment in periods following recessions - with the proportion of employees claiming their work was non-permanent rising from just above 5 percent in 1990 to peak at close to 8 percent in 1997, before declining again, and rising from below 6 percent in 2008 to about 6.5 percent in 2012. Such changes reinforce the perception of a less stable labour market both among workers in general, and academics and commentators.

It is therefore hypothesised that post-recessionary periods are periods of increased generalised job tenures insecurity, regardless of the actual level of involuntary redundancies. Finally, any growth of insecurity among managers and professionals, those deemed to have a greater 'voice', noted above, should be expected to increase generalised job tenure insecurity.

\section{Approach to the data}

The GFGI article uses the Skills and Employment Survey (SES) to measure job tenure insecurity. However, one limitation is the large gaps in the data as the survey was only conducted in 1986, 1997, 2001, 2006 and 2012. The absence of data in the early 1990s is a particular limitation, given the interest here in the impact of the 1991-2 recession. In this article, four sources of time series data on insecurity were examined: SES, British Social Attitudes (BSA), the Workplace Employment Relations Study (WERS) and the British Household Panel Survey (BHPS). Basic information about these surveys is in Table 1. The last of these offered the most consistent annual data but only from 1992-3 through to 2008-9. Studies of subjective insecurity have suffered from a 'scarcity of data' and 'sporadic data availability' that 'make it difficult to tell secular trends from cyclical changes' (Green, 2009:359). A strategy of combining multiple studies was used to counteract this.

\section{[TABLE 1 HERE]}

The survey data are summarised in Tables 2-6. Examination of this data revealed a further reason for considering a range of surveys, namely sensitivity to differing methodologies and questions. For instance, Tables 2 and 3 were taken from the same survey, BSA, and both include entries for 2005. A noticeable difference is that employees were less likely to strongly agree with a statement that they feel secure in their job, even if they claimed to feel 'very secure' regarding their current employment. There was stronger correspondence among employees at the most insecure end of the scale-and indeed the different surveys showed closer agreement here more generally.

[TABLES 2, 3, 4, 5,6 HERE]

The extent to which respondents selected the most extreme response to questions related to job tenure insecurity was taken to measure acute job tenure insecurity. Generalised job tenure 
insecurity was estimated by combining all those responses indicating some level of insecurity about the continuity of employment.

The analysis proceeded as follows. First, the SES data examined by GFGI was broken down and used to illustrate the distinct patterns of evolution of acute and generalised job tenure insecurity. In this case, acute job tenure insecurity was estimated as the proportion of respondents declaring that they were 'very likely' to lose their job in the coming 12 months. This was plotted against the involuntary redundancy rate. The latter was calculated using Labour Force Survey (LFS) data for the years in which the SES data on job security was available: 1986, 1997, 2001, 2006 and 2012. In 1986 the LFS was annual, with fieldwork conducted from March to May. For subsequent years, second quarter (April-June) data was used to maximise consistency and minimise seasonal effects. The rate used was simply the estimated number of involuntary redundancies over the preceding year, divided by the estimated number in employment at the time of the survey. The hypothesis tested here was that acute job tenure insecurity reflects a realistic assessment of the likelihood of job loss. More specifically, it was hypothesised that people's expectations of imminent job loss reflect the scale of job losses in the recent past. Acute job tenure insecurity should, therefore, follow the pattern of involuntary redundancies, and be at roughly similar levels, whereas generalised job tenure insecurity should follow a different path (as well as being considerably more prevalent).

Second, various estimates of generalised job tenure insecurity were plotted together in a single chart. This allowed a more detailed picture of the evolution of this form of insecurity to emerge. The hypothesis here was that generalised job tenure insecurity (like job status insecurity) would rise in the periods following recessions. Given the availability of data, this should mean higher levels of insecurity in the early or mid-1990s and in the aftermath of the 2008-9 recession.

Third, an estimate was made of the extent to which generalised job tenure insecurity has permeated through professional and managerial employment. This was achieved by an F-test of the SES data, first for managers (including supervisors) and non-managers, then for professionals (defined broadly to include managers, technicians and associate professionals) and non-professionals.

\section{Acute job tenure insecurity: a realistic response}

The evolution of acute job tenure insecurity was studied using the SES data, which offered five data points spanning 26 years. Acute job tenure insecurity was defined as the proportion of respondents declaring that they were 'very likely' to lose their job in the coming 12 months. Estimates of acute and generalised job tenure insecurity from SES are plotted for five years between 1986 and 2012 against the 'involuntary redundancy rate' in Figure 1.

\section{[FIGURE 1 HERE]}

The results appear to sustain the idea that acute job tenure insecurity reflects the real likelihood of involuntary job loss over the preceding period (bearing in mind that insecurity is an estimate of 
future likelihood and the redundancy rate is the preceding likelihood). The level of acute job tenure insecurity was slightly above the actual likelihood of involuntary job loss across the years examined, but the difference was never more than 1.5 percent of employees. By contrast, generalised job tenure insecurity has a far less clear relationship to the rate of involuntary redundancy. It rose from 1986 to 1997 even when involuntary redundancies were declining.

Because the rate of involuntary redundancy trended down over the period examined, at least for the years for which data exists in the SES, so too did acute job tenure insecurity.

\section{Mapping generalised job tenure insecurity}

Given that generalised job tenure insecurity does not appear to be driven primarily by the actuality of involuntary redundancies, having not trended down as they have declined, the next step was to generate a more detailed picture of this form of insecurity. This is attempted in Figure 2, which takes any indication of the possibility of job loss as indicative of generalised job tenure insecurity.

[FIGURE 2 HERE]

It is clear from this picture that different measures of insecurity are not directly comparable. Care also has to be taken in interpreting this picture because of the gaps in the various series when examined individually. Nonetheless several features emerge:

- There is no straightforward secular tendency for insecurity to rise through the period studied, affirming and extending the conclusion drawn by Burchell (2002).

- All of the relevant series (WERS, both SES series and BSA2) nonetheless demonstrate a rise in generalised job tenure insecurity post 2008-9.

- Generalised job tenure insecurity appears to be higher in the mid to late 1990s than in the mid to late 1980s (BSA1, the dashed SES measure).

- There is some evidence of a peak in generalised job tenure insecurity around 1993 (BHPS), with insecurity declining thereafter.

- Generalised job tenure insecurity declines in the early 2000s compared to the mid to late 1990s (BSA1, WERS, BHPS, both SES measures).

This supports the hypothesis that post-recessionary periods increase generalised job tenure insecurity. The relatively high, if declining, generalised job tenure insecurity in the mid to late 1990s also fits with the notion that this form of insecurity is heightened by increasing work intensity (Green, 2007).

\section{The spread of insecurity}


Using SES data it was also possible to trace the evolution of managerial and professional insecurity (Tables 7 and 8).

[TABLES 7 AND 8 HERE]

Here periods of heightened generalised job tenure insecurity appear to coincide roughly with periods of convergence between insecurity among managers and non-managers, and professionals and non-professionals. More generally, from 1997 onward there was no significant difference between the generalised job tenure insecurity of 'professionals' (broadly conceived) and the rest of the workforce. These shifts reflect substantial long-term changes to the nature of the 'professions', with growing unionisation among groups such as teachers reflecting the way in which professional privileges have been stripped away in recent decades (Ball 1988; Carter and Stevenson 2012). This has not been seen in the case of managers, although in 1997, and to a lesser extent 2012, managerial insecurity converged with that of non-managers to a degree.

\section{Conclusions}

Based on the data available for the UK, a useful distinction can be made between acute and generalised job tenure insecurity. This approach draws on and extends that of the GFGI article, helping to highlight the fact that different types of job tenure insecurity may be driven by different factors-including those with little bearing on the actual likelihood of job loss.

Here it is argued that acute job tenure insecurity is driven primarily by the actual threat of involuntary redundancy; it is based on a realistic appraisal of the situation faced by employees. Acute job tenure insecurity has tended to decline over recent decades because involuntary redundancy has trended down. Generalised job tenure insecurity is more prevalent throughout recent decades - affecting between a tenth and a fifth of employees, depending on the period and the survey used. This far exceeds the numbers facing the prospect of the loss of their job.

The level of generalised job tenure insecurity depends on wider factors than actual redundancy rates. It is sensitive to economic shifts, and in particular the aftermath of recessions, which have, since the early 1990s led, in the UK at least, to increased job status insecurity and generalised job tenure insecurity among those who retain their job. Furthermore, there is evidence of generalised job tenure insecurity spreading among groups of employees deemed 'professional'.

It is hoped that the distinction here between acute and generalised job tenure insecurity helps inform future research, allowing greater understanding of the drivers of insecurity, which has been identified as one of the challenges facing work and employment in the 21st century. 


\section{Acknowledgements, funding, etc}

The analysis of data presented in this paper was undertaken as part of the author's doctoral studies at Middlesex University Business School from 2014 to 2018. That research was funded by a scholarship generously granted by the university. 


\section{References}

Alberti G, Bessa I, Hardy K, Trappmann V and Umney C (2018) In, against and beyond precarity: work in insecure times. Work, Employment and Society 32(3): 447-457.

Auer $P$ and Cazes S (2000) The resilience of the long-term employment relationship: evidence from the industrialized countries. International Labour Review 139(4): 379-408.

Ball SJ (1988) Staff relations during the teachers' industrial action: Context, conflict and proletarianisation. British Journal of Sociology of Education 9(3): 289-306.

Barbier J (2002) A survey of the use of the term précarité in French economics and sociology. Centre d'Etudes de l'Emploi, working paper 19.

Bernhardt J and Krause A (2014) Flexibility, performance and perceptions of job security: a comparison of East and West German employees in standard employment relationships. Work, Employment and Society 28(2): 285-304.

Bourdieu P (1963) Travail et travailleurs en Algerie. Paris: Mouton \& Co.

Bourdieu P (1998) Acts of Resistance: Against the New Myths of Our Time. Cambridge: Polity.

Burchell B (1994) The effects of labour market position, job insecurity and unemployment on psychological health. In: Gallie D, Marsh C and Vogler C (eds.) Social Change and the Experience of Unemployment. Oxford: Oxford University Press, 188-212.

Burchell B (2002) The prevalence and redistribution of job insecurity and work intensification. In: Burchell B, Ladipo D and Wilkinson F (eds.) Job Insecurity and Work Intensification. London: Routledge, 61-76.

Burgard SA and Seelye S (2016) Histories of perceived job insecurity and psychological distress among older US adults. Society and Mental Health 7(1): 21-35.

Carr E and Chung H (2014) Employment insecurity and life satisfaction: The moderating influence of labour market policies across Europe. Journal of European Social Policy 24(4): 383-399.

Carter B and Stevenson $\mathrm{H}$ (2012) Teachers, workforce remodelling and the challenge to labour process analysis. Work, Employment \& Society 26(3): 481-496.

Cheng $G$ and Chang D (2008) Who suffers more from job insecurity? A meta-analytic review. Applied Psychology: An International Review 57(2): 272-303.

Choonara J (2019) Insecurity, Precarious Work and Labour Markets. London: Palgrave Macmillan.

De Witte $H$ (1999) Job insecurity and psychological well-being: Review of the literature and exploration of some unresolved issues. European Journal of Work and Organizational Psychology 8(2): 157-177.

Deeming C (2015) Foundations of the workfare state-reflections on the political transformation of the welfare state in Britain. Social Policy \& Administration 49(7): 862-886. 
Doogan K (2009) New Capitalism? The Transformation of Work. Cambridge: Polity Press.

Doogan K (2011) Austerity, labour market change and the transformation of work. International Journal of Management Concepts and Philosophy 5(2): 127-137.

Fevre R (2007) Employment insecurity and social theory: the power of nightmares. Work, Employment and Society 21(3): 517-535.

Gallie D, Felstead A, Green F and Hande I (2017) The hidden face of job insecurity. Work, Employment and Society 31(1): 36-53.

Green F (2007) Demanding Work: The Paradox of Job Quality in the Affluent Economy. Princeton: Princeton University Press.

Green F (2009) Subjective employment insecurity around the world. Cambridge Journal of Regions, Economy and Society 2(3): 343-363.

Green F (2011) Job quality in Britain under the Labour government. In: Gregg P and Wadsworth J (eds.) The Labour Market in Winter: The State of Working Britain. Oxford: Oxford University Press, 111-127.

Greenhalgh L and Rosenblatt Z (1984) Job insecurity: toward conceptual clarity. Academy of Management Review 3: 438-48.

Gregg P, Wadsworth J and Faggio G (2011) Job tenure and job turnover. In: Gregg P and Wadsworth $J$ (eds.) The Labour Market in Winter: The State of Working Britain. Oxford: Oxford University Press, 97-107.

Hassard J and Morris J (2018) Contrived competition and manufactured uncertainty: Understanding managerial job insecurity narratives in large corporations. Work, Employment and Society 32(3): 564580.

Keim A, Landis R, Pierce C and Earnest D (2014) Why do employees worry about their jobs? A metaanalytic review of predictors of job insecurity. Journal of Applied Health Psychology 19(3): 269-290.

Lowe TS (2018) Perceived job and labour market insecurity in the United States: An assessment of workers' attitudes from 2002 to 2014. Work and Occupations 45(3): 313-345.

Lozza E, Libreri C and Bosio A (2013) Temporary employment, job insecurity and their extraorganizational outcomes. Economic and Industrial Democracy 34(1): 89-105.

McGann M, White K and Moss J (2016) Labour casualization and the psychosocial health of workers in Australia. Work, Employment and Society 30(5): 766-782.

Overell S, Mills T, Roberts S, Lekhi R and Blaug R (2010) The Employment Relationship and the Quality of Work. London: The Work Foundation.

Sverke $M$ and Hellgren J (2002) The nature of job insecurity: Understanding employment uncertainty on the brink of a new millennium. Applied Psychology 51(1): 23-42. 
Wanrooy BV, Bewley H, Bryson A, Forth J, Freeth S, Stokes L and Wood S (2013) The 2011 Workplace Employment Relations Study: First Findings. London: Department for Business, Innovation \& Skills. 


\section{Author biography}

Joseph Choonara is a lecturer in political economy at the University of Leicester School of Business.

His research interests include: employment precarity and insecurity, social class, and the drivers and consequences of economic crises. 
Tables

Table 1. Sources of data.

\begin{tabular}{|l|l|l|l|}
\hline $\begin{array}{l}\text { Survey } \\
\text { *name changes between } \\
\text { iterations }\end{array}$ & $\begin{array}{l}\text { Approximate } \\
\text { sample size }\end{array}$ & $\begin{array}{l}\text { Period } \\
\text { covered }\end{array}$ & Agencies responsible \\
\hline Skills and Employment Survey* & 3,200 & $1986-2012$ & $\begin{array}{l}\text { Economic and Social Research Council } \\
\text { (ESRC) and UK Commission for } \\
\text { Employment and Skills (UKCES) }\end{array}$ \\
\hline $\begin{array}{l}\text { Workplace Employment } \\
\text { Relations Survey* }\end{array}$ & 22,000 & $1980-2011$ & $\begin{array}{l}\text { Department for Business, Innovation } \\
\text { and Skills; ESRC; Advisory, Conciliation } \\
\text { and Arbitration Service; UKCES; and } \\
\text { National Institute of Economic and } \\
\text { Social Research }\end{array}$ \\
\hline British Social Attitudes & 3,000 & $1983-$ & NatCen Social Research \\
\hline British Household Panel Survey & 10,000 & $1991-2009$ & $\begin{array}{l}\text { Institute for Social and Economic } \\
\text { Research and ESRC }\end{array}$ \\
\hline
\end{tabular}

Table 2. BSA data 1.

\begin{tabular}{|l|r|r|r|}
\hline $\begin{array}{l}\text { Do you agree with the statement: } \\
\text { 'My job is secure'? }\end{array}$ & $\mathbf{1 9 8 9}$ & $\mathbf{1 9 9 7}$ & $\mathbf{2 0 0 5}$ \\
\hline Strongly agree & $17.2 \%$ & $12.2 \%$ & $18.6 \%$ \\
\hline Agree & $41.0 \%$ & $40.2 \%$ & $49.7 \%$ \\
\hline Neither agree nor disagree & $21.7 \%$ & $19.3 \%$ & $18.2 \%$ \\
\hline Disagree & $15.2 \%$ & $21.8 \%$ & $10.6 \%$ \\
\hline Strongly disagree & $5.0 \%$ & $6.4 \%$ & $2.9 \%$ \\
\hline
\end{tabular}

Table 3. BSA data 2.

\begin{tabular}{|l|r|r|r|}
\hline $\begin{array}{l}\text { How secure do you feel your } \\
\text { employment is with your present } \\
\text { employer? }\end{array}$ & $\mathbf{2 0 0 5}$ & $\mathbf{2 0 0 9}$ & $\mathbf{2 0 1 0}$ \\
\hline Very secure & $37.3 \%$ & $29.8 \%$ & $26.1 \%$ \\
\hline Secure & $40.6 \%$ & $46.0 \%$ & $46.4 \%$ \\
\hline Neither secure nor insecure & $12.8 \%$ & $15.6 \%$ & $17.5 \%$ \\
\hline Insecure & $7.1 \%$ & $6.1 \%$ & $7.7 \%$ \\
\hline Very insecure & $2.3 \%$ & $2.5 \%$ & $2.2 \%$ \\
\hline
\end{tabular}

Table 4. SES data.

\begin{tabular}{|l|r|r|r|r|r|}
\hline $\begin{array}{l}\text { Perceived likelihood of } \\
\text { losing job in next 12 } \\
\text { months }\end{array}$ & $\mathbf{1 9 8 6}$ & $\mathbf{1 9 9 7}$ & $\mathbf{2 0 0 1}$ & $\mathbf{2 0 0 6}$ & $\mathbf{2 0 1 2}$ \\
\hline None & $\mathbf{7 9 . 7 \%}$ & $\mathbf{7 7 . 0 \%}$ & $83.5 \%$ & $82.3 \%$ & $74.7 \%$ \\
\hline Very unlikely & $1.3 \%$ & $1.3 \%$ & $1.0 \%$ & $0.7 \%$ & $0.8 \%$ \\
\hline Quite unlikely & $3.6 \%$ & $5.3 \%$ & $3.7 \%$ & $4.4 \%$ & $6.2 \%$ \\
\hline Evens & $6.7 \%$ & $9.4 \%$ & $5.8 \%$ & $6.9 \%$ & $10.5 \%$ \\
\hline Quite likely & $4.0 \%$ & $3.4 \%$ & $3.1 \%$ & $3.4 \%$ & $5.0 \%$ \\
\hline Very likely & $4.6 \%$ & $3.6 \%$ & $2.9 \%$ & $2.4 \%$ & $2.8 \%$ \\
\hline
\end{tabular}


Table 5. WERS data.

\begin{tabular}{|l|r|r|r|}
\hline 'I feel my job is secure in this workplace' & $\mathbf{1 9 9 8}$ & $\mathbf{2 0 0 4}$ & $\mathbf{2 0 1 1}$ \\
\hline Strong agree & $13.2 \%$ & $19.0 \%$ & $16.6 \%$ \\
\hline Agree & $46.8 \%$ & $48.1 \%$ & $43.9 \%$ \\
\hline Neither agree nor disagree & $20.7 \%$ & $18.0 \%$ & $21.1 \%$ \\
\hline Disagree & $14.0 \%$ & $11.1 \%$ & $13.3 \%$ \\
\hline Strongly disagree & $5.3 \%$ & $4.0 \%$ & $5.1 \%$ \\
\hline
\end{tabular}

Table 6. BHPS data.

\begin{tabular}{|l|r|r|r|r|r|r|r|}
\hline & \multicolumn{7}{|l|}{$\begin{array}{l}\text { Degree of satisfaction with job security } \\
\text { 1='not at all satisfied'; } 4 \text { '`neither satisfied nor dissatisfied'; 7='completely satisfied' }\end{array}$} \\
\hline Years & $\mathbf{1}$ & $\mathbf{2}$ & $\mathbf{3}$ & $\mathbf{4}$ & $\mathbf{5}$ & $\mathbf{6}$ & $\mathbf{7}$ \\
\hline $1992-3$ & $6.0 \%$ & $3.6 \%$ & $9.2 \%$ & $11.4 \%$ & $17.4 \%$ & $28.3 \%$ & $24.2 \%$ \\
\hline $1993-4$ & $5.1 \%$ & $4.3 \%$ & $10.0 \%$ & $10.9 \%$ & $17.3 \%$ & $30.2 \%$ & $22.1 \%$ \\
\hline $1994-5$ & $6.1 \%$ & $4.1 \%$ & $8.4 \%$ & $10.9 \%$ & $18.2 \%$ & $30.4 \%$ & $21.9 \%$ \\
\hline $1995-6$ & $4.7 \%$ & $3.6 \%$ & $8.5 \%$ & $10.6 \%$ & $18.7 \%$ & $32.3 \%$ & $21.6 \%$ \\
\hline $1996-7$ & $4.0 \%$ & $3.4 \%$ & $8.0 \%$ & $10.9 \%$ & $17.5 \%$ & $33.0 \%$ & $23.3 \%$ \\
\hline $1997-8$ & $3.5 \%$ & $2.9 \%$ & $6.9 \%$ & $9.6 \%$ & $18.1 \%$ & $34.6 \%$ & $24.3 \%$ \\
\hline $1998-9$ & $2.4 \%$ & $2.8 \%$ & $7.0 \%$ & $9.4 \%$ & $19.3 \%$ & $36.3 \%$ & $22.8 \%$ \\
\hline $1999-2000$ & $3.0 \%$ & $3.8 \%$ & $7.0 \%$ & $7.7 \%$ & $17.2 \%$ & $39.5 \%$ & $21.8 \%$ \\
\hline $2000-1$ & $2.2 \%$ & $3.0 \%$ & $6.3 \%$ & $8.9 \%$ & $19.3 \%$ & $40.2 \%$ & $20.1 \%$ \\
\hline $2001-2$ & $2.4 \%$ & $2.2 \%$ & $6.6 \%$ & $8.2 \%$ & $19.9 \%$ & $39.3 \%$ & $21.2 \%$ \\
\hline $2002-3$ & $2.3 \%$ & $2.4 \%$ & $6.5 \%$ & $7.5 \%$ & $18.4 \%$ & $41.4 \%$ & $21.5 \%$ \\
\hline $2003-4$ & $1.5 \%$ & $2.6 \%$ & $6.5 \%$ & $7.9 \%$ & $18.7 \%$ & $41.0 \%$ & $21.8 \%$ \\
\hline $2004-5$ & $1.9 \%$ & $2.4 \%$ & $5.6 \%$ & $7.8 \%$ & $17.8 \%$ & $41.7 \%$ & $22.8 \%$ \\
\hline $2005-6$ & $1.8 \%$ & $2.2 \%$ & $6.6 \%$ & $7.8 \%$ & $18.5 \%$ & $40.7 \%$ & $22.5 \%$ \\
\hline $2006-7$ & $2.3 \%$ & $2.3 \%$ & $6.4 \%$ & $7.1 \%$ & $20.4 \%$ & $40.0 \%$ & $21.4 \%$ \\
\hline $2007-8$ & $1.9 \%$ & $2.2 \%$ & $5.8 \%$ & $7.4 \%$ & $19.0 \%$ & $41.9 \%$ & $21.8 \%$ \\
\hline $2008-9$ & $1.7 \%$ & $2.6 \%$ & $5.8 \%$ & $8.3 \%$ & $22.8 \%$ & $40.0 \%$ & $18.8 \%$ \\
\hline
\end{tabular}

Table 7. SES data.

\begin{tabular}{|l|r|l|l|}
\cline { 2 - 4 } \multicolumn{1}{c|}{ Generalised job tenure insecurity } & \multicolumn{1}{l}{} \\
\cline { 2 - 5 } \multicolumn{1}{c|}{} & Managers and supervisors & Others & Prob > F \\
\hline $\mathbf{1 9 8 6}$ & $10.4 \%$ & $19.1 \%$ & $0.0000^{* *}$ \\
\hline $\mathbf{1 9 9 7}$ & $14.3 \%$ & $17.6 \%$ & 0.0591 \\
\hline $\mathbf{2 0 0 1}$ & $9.5 \%$ & $14.2 \%$ & $0.0000^{* *}$ \\
\hline $\mathbf{2 0 0 6}$ & $9.8 \%$ & $15.8 \%$ & $0.0000^{* *}$ \\
\hline $\mathbf{2 0 1 2}$ & $15.6 \%$ & $19.6 \%$ & $0.0334^{*}$ \\
\hline
\end{tabular}

${ }^{* *}=$ difference significant at $1 \%$ level, ${ }^{*}=$ difference significant at $5 \%$ level 
Table 8. SES data.

\begin{tabular}{|l|l|l|l|}
\cline { 2 - 4 } \multicolumn{1}{c|}{} & \multicolumn{2}{l}{ Generalised job tenure insecurity } & \multirow{2}{*}{} \\
\cline { 2 - 4 } & $\begin{array}{l}\text { Senior officials, managers, } \\
\text { professionals, technicians } \\
\text { and associate professionals }\end{array}$ & Others & \\
\hline $\mathbf{1 9 8 6}$ & $12.2 \%$ & $17.1 \%$ & $0.0004 * *$ \\
\hline $\mathbf{1 9 9 7}$ & $16.4 \%$ & $16.1 \%$ & 0.8795 \\
\hline $\mathbf{2 0 0 1}$ & $11.1 \%$ & $12.9 \%$ & 0.1456 \\
\hline $\mathbf{2 0 0 6}$ & $12.3 \%$ & $13.9 \%$ & 0.1680 \\
\hline $\mathbf{2 0 1 2}$ & $16.0 \%$ & $19.3 \%$ & 0.0765 \\
\hline
\end{tabular}

$*^{*}=$ difference significant at $1 \%$ level, ${ }^{*}=$ difference significant at $5 \%$ level 


\section{Figures}

Figure 1. Insecurity and involuntary redundancy rates (selected years)

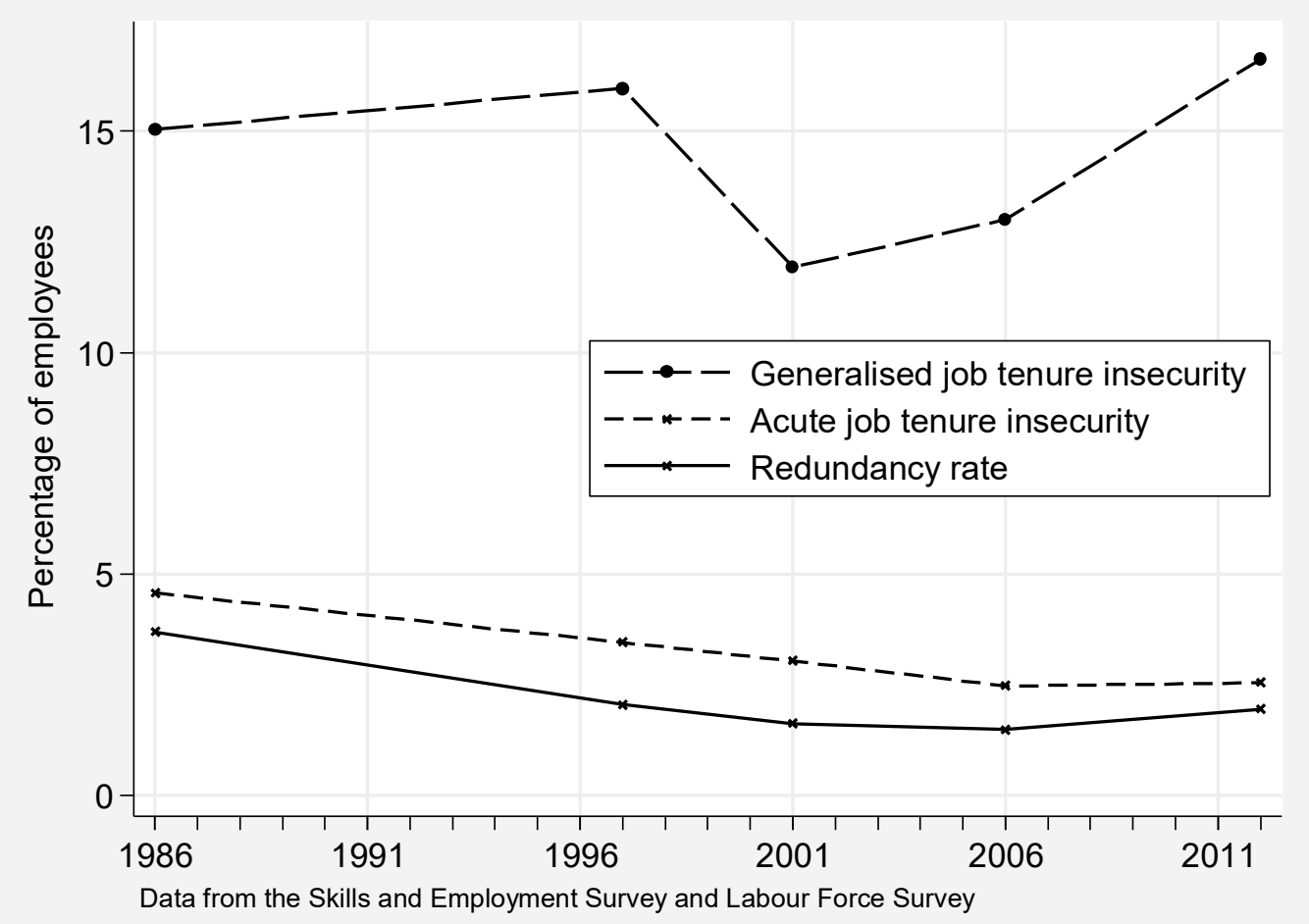


Figure 2. Generalised job tenure insecurity.

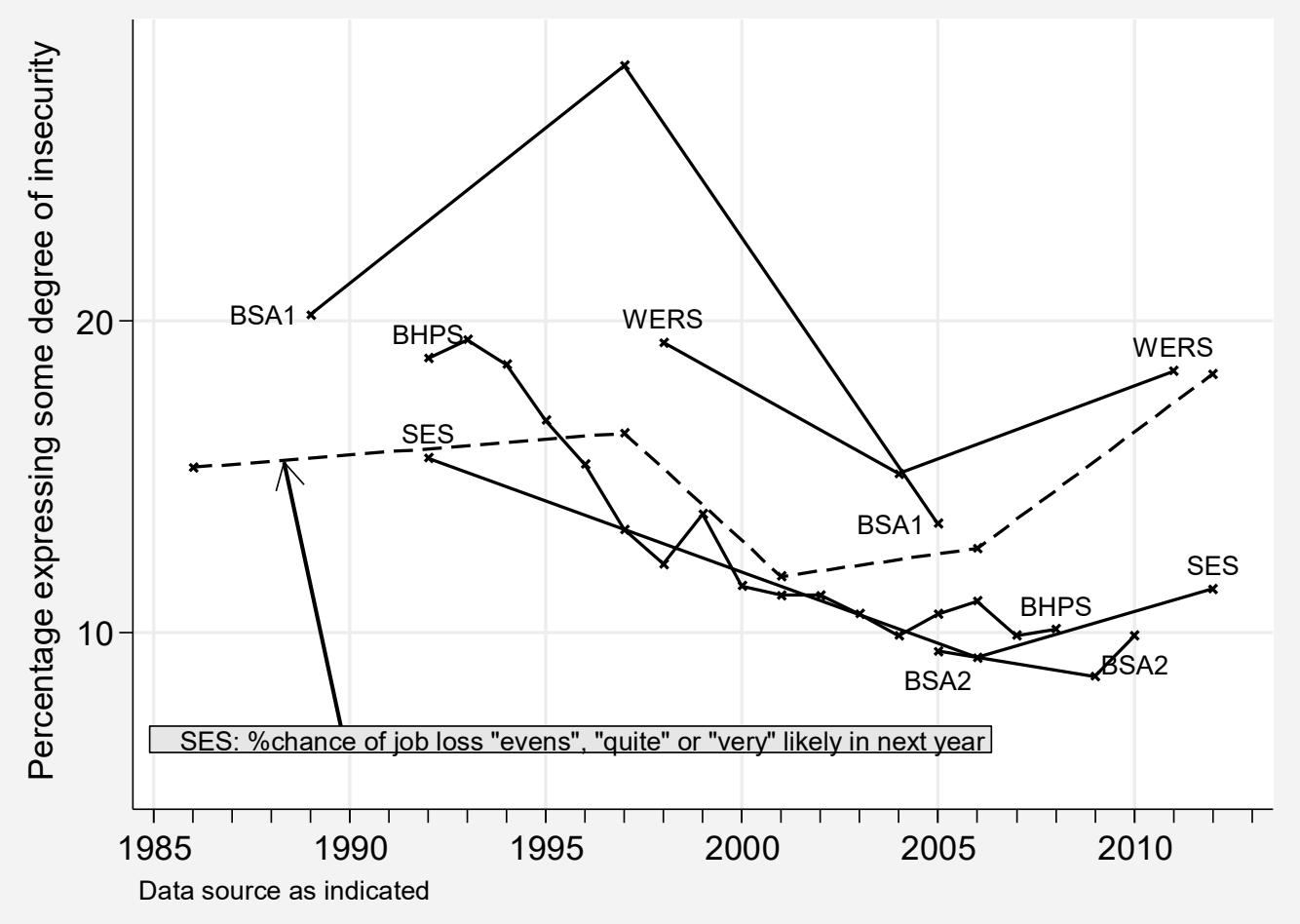

